TITLE:

\title{
Pyrolysis behaviors of wood and its constituent polymers at gasification temperature
}

$\operatorname{AUTHOR}(S)$ :

Hosoya, T.; Kawamoto, H.; Saka, S.

\section{CITATION:}

Hosoya, T.... [et al]. Pyrolysis behaviors of wood and its constituent polymers at gasification temperature. Journal of Analytical and Applied Pyrolysis 2007, 78(2): 328-336

ISSUE DATE:

2007-03

URL:

http://hdl.handle.net/2433/240780

\section{RIGHT:}

(c) 2006. This manuscript version is made available under the CC-BY-NC-ND 4.0 license

http://creativecommons.org/licenses/by-nc-nd/4.0/; The full-text file will be made open to the public on 1 March 2009 in accordance with publisher's 'Terms and Conditions for Self-Archiving'.; この論文は出版社版でありません。引用の際 には出版社版をご確認ご利用ください。; This is not the published version. Please cite only the published version. 
Title:

Pyrolysis Behaviors of Wood and its Constituent Polymers at Gasification

\section{Temperature}

\section{Authors:}

\section{T. Hosoya, H. Kawamoto*, S. Saka}

* Corresponding author: Tal/Fax: +81-75-753-4737

Email address: kawamoto@energy.kyoto-u.ac.jp (H. Kawamoto)

Full postal address of the person to whom proofs are to be sent:

Graduate School of Energy Science, Kyoto University

Yoshida-honmachi, Sakyo-ku, Kyoto 606-8501, Japan

Number of pages: 23

Number of tables: 6

Number of Figures: 7 


\section{ABSTRACT}

Pyrolysis behavior of wood at gasification temperature $\left(800{ }^{\circ} \mathrm{C}\right)$ was investigated focusing on the behaviors of the wood constituent polymers [cellulose, hemicellulose (glucomannan and xylan) and lignin (milled wood lignin)]. Tar compositions (iso-propanol-soluble and water-soluble tar fractions), which were characterized with GPC, GC-MS, GC-FID (oxime-TMS analysis), capillary electrophoresis and ${ }^{1} \mathrm{H}$ NMR analysis, were quite different between wood polysaccharides and lignin. Furthermore, comparison of the tar- and secondary char-forming behaviors indicated that comparatively stable primary tar from wood polysaccharides undergo secondary reactions including carbonization after condensation at the reactor wall with lower temperature than their boiling points, while that primary tar from lignin is more reactive to give the vapor phase carbonization products during volatilization.

Keywords: wood, biomass, gasification, pyrolysis, tar, cellulose, hemicellulose, glucomannan, xylan, lignin 


\section{INTRODUCTION}

Gasification is a potential way to convert woody biomass into electricity, liquid fuels and chemicals as well as gaseous fuels. However, tar problem exists as a major challenging technical issue for its commercialization [1,2]. Many attempts have been conducted to reduce the tarry by-products which include their physical removal [1,2] with bag filter and electrostatic precipitation and catalytic cracking [1-3] with dolomite, alkali metal salts, nickel-supposed catalysts and so on.

Gasification is considered as a two-stage process, which includes primary pyrolysis to form primary tar and char, followed by their reactions with gasifying agents such as oxygen and steam [4]. In this process, the primary pyrolysis must be important for final product composition through acting as a source of the reactants with gasifying agents. Thus, understanding the primary pyrolysis behavior of wood to form volatile and carbonized products and their reactions with gasification agents are very important to understande the overall gasification process on molecular basis. However, molecular mechanisms involved in these processes have not been fully elucidated yet.

This paper focuses on the primary pyrolysis in wood gasification. Primary pyrolysis has been studied as a fast pyrolysis behavior of wood mainly with the mass-loss behavior [5-7] and mass spectrometric analysis of the volatile products including curie-point pyrolysis-gas chromatography/mass spectrometry (py-GC/MS) [8-10] and molecular-beam mass spectrometric technique [11]. However, the primary pyrolysis behavior at gasification temperature has not been 
studied well. Furthermore, with these mass spectrometric techniques, it is difficult to analyze high molecular-weight (MW) products and their reactivities for secondary carbonization. For understanding the primary pyrolysis on molecular basis, it is necessary to characterize whole products in pyrolysis. In this paper, wood primary pyrolysis behavior at gasification temperature including volatile composition and secondary char formation is presented focusing on the difference between wood constituent polymers.

\section{EXPERIMANTAL}

\subsection{Materials}

Japanese cedar (Cryptomeria japonica) wood flour ( $<80$ mesh) was pre-extracted with ethanol/benzene (2:1, v/v) for $6 \mathrm{~h}$. Cellulose powder (200-300 mesh) (Toyoroshi co.) and xylan from beech wood (Sigma co.) were used as commercial samples. Glucomannan and milled wood lignin (MWL) were isolated and purified from Japanese cedar wood according to the methods described in the literature [12] and [13], respectively. Glucomannan and xylan were used after demineralization by washing with $0.05 \mathrm{M} \mathrm{HCl} / \mathrm{MeOH}$ at room temperature for $24 \mathrm{~h}$ twice and subsequently with $\mathrm{MeOH}$ repeatedly until the electronic conductivity of the washing become constant. Table 1 summarizes the moisture, ash and hydrolysable sugar contents of these samples. Moisture content was determined from the decrease in weight after heating at $105^{\circ} \mathrm{C}$ for $24 \mathrm{~h}$. Ash 
content was determined as the amount of the residue at $600^{\circ} \mathrm{C}$ in thermogravimetric analysis in air at a heating rate of $10^{\circ} \mathrm{C} / \mathrm{min}$ with a Shimadzu TGA 50 apparatus. Hydrolysable sugar contents were determined with the alditol-acetate method [14] after hydrolysis under the conditions (72 \% aqueous $\mathrm{H}_{2} \mathrm{SO}_{4}$ / room temperature/ $1 \mathrm{~h}$, then $3.0 \%$ aqueous $\left.\mathrm{H}_{2} \mathrm{SO}_{4} / 100{ }^{\circ} \mathrm{C} / 1 \mathrm{~h}\right)$. Number average of MW of the MWL was about 5000 as polystyrene standards.

\subsection{Pyrolysis}

Pyrolysis was conducted with the apparatus shown in Fig. 1. Sample (50 mg) was placed at the bottom of a tube reactor made of Pyrex glass (internal diameter: $10 \mathrm{~mm}$, length: $300 \mathrm{~mm}$ ), and gas bag and nitrogen bag were connected to the reactor through valves 1 and 2, respectively. Before insetting the reactor into the furnace, the valve 1 was opened and the air in the system was pumped out with aspirator and replaced with nitrogen through the valve 2. This procedure was repeated three times. Pyrolysis was conducted by inserting the reactor into the cylindrical furnace preheated at $800{ }^{\circ} \mathrm{C}$ (center of the furnace). The bottom of the tube reactor was placed at the center of the heated zone of the cylindrical furnace. During pyrolysis, the valve 1 was opened and the valve 2 was closed to maintain the inside of the reactor at atmospheric pressure. Temperature profile in the cylindrical furnace (Fig. 2) was obtained by measuring the temperature with thermocouple inserted at various site of the furnace. Temperature of each part of the reactor was 
expected to be raised immediately up to the temperature in Fig. 2. After $30 \mathrm{~s}$ pyrolysis, the reactor was pulled out from the furnace and cooled with air flow for $1 \mathrm{~min}$ at room temperature. Thirty seconds were enough for completing the pyrolysis since no volatile product formation was observed after longer pyrolysis time.

The reaction mixture was extracted with $1.0 \mathrm{ml}$ of iso-propanol (i-PrOH) twice and then with $1.0 \mathrm{ml}$ of water twice to give an $i$-PrOH-soluble and a water-soluble tar fraction. The resulting insoluble residue with dark color was defined as a char fraction in this paper. Two types of the carbonized products were observed in this experiment; one was formed at the bottom of the reactor where the sample was placed and this is defined as "primary char". The other carbonized product (defined as "secondary char") was formed at the upper side of the reactor after volatilization. The amounts of gaseous, tar and char fractions were determined from the weight difference of the reactor after pyrolysis or extraction. At least three sets of the experiment were carried out for one pyrolysis conditions, and all results were found to be reproducible.

Other three sets of the pyrolysis were conducted separately under the same pyrolysis conditions to obtain acetone- $d_{6}, N, N^{\prime}$-dimethylformamide (DMF) and water extracts to characterize the pyrolysis products as described in the following session. These extracts were obtained by extracting the pyrolysis mixture with these solvents $(1.0 \mathrm{ml} \mathrm{x} 2)$. 
2.3 Characterization of the products

Pyrolysis products except for the carbonized products were characterized with several methods summarized in Table 2 .

Gel permeation chromatographic (GPC) analysis was carried out for i-PrOH-soluble and water-soluble fractions using Shimadzu LC-10A under the following conditions: column: Shodex KF $801+$ KF $802+$ KF 802.5 + KF 803L, flow rate: 0.6 ml/min, eluent: THF, detector: SPD (UV $220 \mathrm{~nm}$ ), temperature: $40{ }^{\circ} \mathrm{C}$. Water-soluble fraction was acetylated under the conditions (acetic anhydride/ pyridine/ room temperature/ over night) before GPC analysis.

To identify the low MW products in i-PrOH-soluble fraction, gas chromatography-mass spectrometric (GC-MS) analysis was carried out for qualitative analysis of low MW products in i-PrOH-soluble fraction using Hitachi G-7000 gas chromatograph and Hitachi M9000 mass spectrometer under the following conditions: column: Shimadzu CBP-M25-O25 (length: $25 \mathrm{~m}$, diameter: $0.25 \mathrm{~mm}$ ), injector temperature: $250{ }^{\circ} \mathrm{C}$, column temperature: $30^{\circ} \mathrm{C}(1 \mathrm{~min}), 30 \rightarrow 250$ ${ }^{\circ} \mathrm{C}(1 \rightarrow 111 \mathrm{~min}), 250{ }^{\circ} \mathrm{C}(111 \rightarrow 121 \mathrm{~min})$, carrier gas: helium, flow rate: $1.5 \mathrm{ml} / \mathrm{min}$, emission current: $20 \mu \mathrm{A}$, ionization time: $25 \mathrm{~ms}$.

${ }^{1} \mathrm{H}$ NMR analysis was conducted to characterize the whole products including high MW substances in $i-\mathrm{PrOH}-$ soluble fraction with a Bruker AC-400 $(400 \mathrm{MHz})$ spectrometer in acetone- $d_{6}$ after evaporation of the $i$-PrOH-soluble fraction in vacuo to remove $i$-PrOH. Chemical shifts are 
shown as $\delta$ value with tetramethylsilane as an internal standard.

Hydrolysable sugar content of water-soluble fraction was determined with the alditol-acetate

method. Water-soluble fraction was hydrolyzed in $2 N$-trifuluoroaceticacid aqueous solution at 100

${ }^{\circ} \mathrm{C}$ for $1 \mathrm{~h}$, and the monosaccharides formed were quantitatively analyzed as alditol-acetates after successive $\mathrm{NaBH}_{4}$ reduction $\left(\mathrm{NaBH}_{4} / \mathrm{H}_{2} \mathrm{O} /\right.$ room temperature/ 2 h) and acetylation (acetic anhydride/ pyridine/ room temperature/ over night).

Although product water and the water in sample were included in the $i$-PrOH-soluble fraction, the yield of the $i$-PrOH-soluble fraction shown in this paper excludes the water. The water content in the $i-\mathrm{PrOH}$-soluble fraction was estimated from the ${ }^{1} \mathrm{H}$ NMR analysis of the acetone- $d_{6}$ extracts based on the peak area of the water proton signal $(\delta$ 2.8-3.2 ppm). Yield of product water was calculated by subtracting the moisture in sample from the water content determined.

Gas chromatographic analysis [flame ionization detector (FID)] after oximation-trimethylsilylation was conducted for DMF extracts to quantify the major low MW products from wood polysaccharides (oxime-TMS analysis). The detailed procedure is described in the previous paper [15].

Capillary electrophoresis (CE) analysis was carried out for water extracts to quantify the carboxylic acids with an Aglient HP3D CE system under the following conditions: column: fused-silica capillary (length: $104 \mathrm{~cm}$, diameter: $75 \mu \mathrm{m}$ ), buffer: 2,6-pyridinedicarboxylic acid buffer 
containing $0.5 \mathrm{mM}$ acetyltrimethylammonium bromide (pH 5.6 ) (Aglient co.), voltage: -30kV, temperature: $15^{\circ} \mathrm{C}$, detector: $\mathrm{UV}_{270 \mathrm{~nm}}$, migration times: formic acid (9.3 min), acetic acid (11.2 min) and glycolic acid (11.7 min).

\section{RESULTS AND DISCUSSION}

3.1 Tar and char formation behavior

Figure 2 shows the reactors after pyrolysis in $\mathrm{N}_{2}$ at $800{ }^{\circ} \mathrm{C}$ for $30 \mathrm{~s}$ with the temperature profile of the reactor. Both $i$-PrOH- and water-soluble fractions from wood polysaccharide samples and MWL were recovered form the upper part (> $14 \mathrm{~cm}$ from the bottom) of the reactor wall with the corresponding wall temperature of less than $400^{\circ} \mathrm{C}$.

Secondary char (char after volatilization) formation behavior was different between wood polysaccharide samples and MWL. Wood polysaccharide samples (cellulose, glucomannan and xylan) formed secondary char at the reactor wall $(10-16 \mathrm{~cm}$ from the bottom) and this was very close to the place where tar fractions were recovered. Only very small amount of carbonized products were observed around 2-10 cm from the bottom of the reactor. On the other hand, secondary char from lignin was observed from the bottom to the upper side of the reactor continuously. These 
differences would derive from the different reactivities of the volatile products toward carbonization as described later.

\subsection{Fractional composition of the pyrolysis products}

Table 3 summarizes the fractional compositions (oven dry basis) of the pyrolysis products.

Cellulose formed small amount (10.0 wt\%) of char with large amount (72.0 wt\%) of the tar fraction,

while MWL (lignin) produced large amount (40.6 wt\%) of char with comparatively small amount (38.2 wt \%) of the tar fraction. Hemicellulose (glucomannan and xylan) showed the tendency between cellulose and MWL. These results are also supported with the papers [5-7].

The amount of the product water was positively related with the amount of the char fraction in the wood polysaccharides pyrolysis. MWL produced much less amount of the product water although substantial amount of the char fraction is formed. These differences are understandable with their different chemical structures. Lignin has aromatic rings which are in more dehydrated states than the sugar moiety of wood polysaccharides. It is also noted that wood polysaccharide samples, especially cellulose, formed substantial amounts (5.2-21.6 wt\%) of the water-soluble fractions.

3.3 Characterization of tar fractions 


\subsection{1 $i$-PrOH-soluble fraction}

Figure 3 shows the GPC chromatograms (Detector: $\mathrm{UV}_{220 \mathrm{~nm}}$ ) of the $i$-PrOH-soluble fractions.

Although the products analyzed in these chromatograms are only those with the adsorbing ability of $\mathrm{UV}_{220 \mathrm{~nm}}$, the products are observed in wide MW ranges of 100-2000 as polystyrene standard.

These results indicate that the $i-\mathrm{PrOH}$ soluble fractions contain certain amount of high MW products, which are difficult to be analyzed with GC. With refractive index (RI) detector, GPC analysis was difficult due to a large peak of the solvent, $i-\mathrm{PrOH}$. The chromatographic pattern obtained from wood is observed as a sum of those from wood polysaccharides and MWL.

Figure 4 shows the total-ion chromatograms of the $i-\mathrm{PrOH}$-soluble fractions in their GC-MS analysis. Identification of the products was conducted with the retention times and mass fragmentation patterns compared with those of the authentic compounds. Table 4 summarized the identification results with their major mass fragments. Identification of compounds 6, 7, 11 and 24 was carried out by comparing their mass fragmentation patterns with those reported in the literature $[9,10,16,17]$.

Wood polysaccharide samples formed the products categorized into $\mathrm{C}_{2}-\mathrm{C}_{3}$ carbonyls, anhydrosugars, carboxylic acids, furans and $\mathrm{C}_{5}-\mathrm{C}_{6}$ carbonyls, although their yields were different between wood polysaccharide types. 2-Hydroxymethylene-tetrahydrofuran-3-one (7) is a specific product in xylan pyrolysis, which was originally reported by Miyazaki [16] with revision of the 
chemical structure later by Gomez-Pardo and d'Angolo [17]. Compound 15 with an expected MW of 114 is also observed as a large peak. Although compound $\mathbf{1 5}$ has not been identified yet, Henser and Scherer [18] isolated the crystals with the same MW and different melting point from compound 7 in the syrup obtained by dry distillation of xylan. Benzene-type aromatic compounds were not detected from wood polysaccharide samples.

On the other hand, aromatic monomers with 4-hydroxy-3-methoxyphenyl (guaiacyl) moiety, which is the consistent aromatic ring of Japanese cedar wood lignin, were mainly identified in the i-PrOH-soluble fraction from MWL. Many of these products contain carbonyl and/or $\mathrm{C}_{\alpha}=\mathrm{C}_{\beta}$ groups. Dimeric aromatic compounds were scarcely observed in the chromatograms probably due to their low volatility. It is also noted that demethylation products such as catecol-type compounds, which are expected to be formed through homolytic cleavage of phenyl-methyl ether at this temperature, were scarcely observed in the chromatogram.

Table 5 summarizes the yields (oven dry basis) of some major products from wood polysaccharides determined by oxime-TMS analysis [15] (for $\mathrm{C}_{2}-\mathrm{C}_{3}$ carbonyls, anhydrosugars and furans) and CE (for carboxylic acids). Total yields of these products correspond to 18.7-43.7 wt\% of the $i$-PrOH-soluble fractions.

High MW products of the $i$-PrOH-soluble fraction, which could not be characterized by GC-MS due to their low volatility, were characterized with their ${ }^{1} \mathrm{H}$ NMR spectra. $\quad{ }^{1} \mathrm{H}$ NMR spectra 
(in aceton- $d_{6}$ ) of the $i$-PrOH-soluble fraction after evaporation in vacuo are shown in Fig. 5. Although sharp signals corresponding to the low MW products are different depending on the wood polysaccharide types, broad signals are mainly observed around 3-5 ppm in the spectra from all polysaccharides samples. Addition of $\mathrm{D}_{2} \mathrm{O}$ reduced the peak area of the broad signals around 3-5 ppm, and this indicates the existence of the signals assigned to the hydroxyl groups. From these spectrometric data, signals around 3-5 ppm are considered to be derived from the protons of the H-C-O- and hydroxyl structures. These results indicate that high MW products in the $i$-PrOH-soluble fractions from wood polysaccharide samples have the structures which are not altered substantially from the sugar structure.

Some of the sharp peaks in the spectra from cellulose and glucomannan were assigned to those of levoglucosan $(\bullet)$, levomannosan (०) and 5-hydroxymethylfurfural (5-HMF) (๘) by comparing with the spectra of these authentic compounds. Other low MW products in Table 5 were not observed due to their removal during the evaporation process. By comparing with the spectra of 5-HMF, some of the signals at 6-8 and around $10 \mathrm{ppm}$ would derive from the protons with $\mathrm{C}=\mathrm{C}$ structures and aldehyde protons, respectively. Consequently, as indicated in the low MW product composition, benzene-type aromatic structure is not important also in the high MW products in the $i$-PrOH-soluble fractions from wood polysaccharide samples.

Milled wood lignin gave a quite different spectrum, in which strong signals are observed 
around 6.5-8.0 and 3.5-4.0 ppm. These signals are assigned to the protons of the aromatic (benzene-type) structures and methoxyl groups, respectively. Furthermore, shape of these peaks is quite similar to that of the 4-hydroxy-3-methoxy phenyl (guaiacyl) moiety. These results indicate that high MW products from MWL also mainly consist of the guaiacyl structures, as indicated in the analysis of the low MW products.

From these lines of evidence, $i$-PrOH-soluble fractions were found to be quite different in chemical composition between wood polysaccharides and lignin: $\mathrm{C}_{2}-\mathrm{C}_{3}$ carbonyls, carboxylic acids, anhydrosugars, furans, $\mathrm{C}_{5}-\mathrm{C}_{6}$ carbonyls and sugar-like substances (from wood polysaccharides); monomeric and oligomeric aromatic (benzene-type) compounds with guaiacyl moiety (form lignin).

\subsubsection{Water-soluble fraction}

Figure 6 shows the GPC chromatograms of the water-soluble fractions of wood and wood polysaccharide samples after acetylation. The acetylated water-soluble fractions from wood polysaccharide samples include high MW products more than MW 13100 as polystyrene standard, which are much higher than those (100-2000) of the $i-\mathrm{PrOH}$-soluble fractions as shown in Fig. 3 . It is noted that water-soluble fraction from wood is observed only in relatively low MW region.

Table 6 summarizes the hydrolysable sugar contents of the water-soluble fractions. Hydrolysable sugar contents from wood polysaccharide samples were $20.6-25.8 \mathrm{wt} \%$ based on the 
yields of the water-soluble fraction. These results indicate that the water-soluble fractions from wood polysaccharide samples include polysaccharide-based substances. Small amount (0.73 wt\%) of xylose in the hydrolysate from glucomannan may be derived from the xylan contamination in the glucomannan sample as indicated in Table 1.

Polysaccharide is reported also in the tar fraction obtained in cellulose pyrolysis at $300{ }^{\circ} \mathrm{C}$ [19]. Pictet reported that levoglucosan polymerize into polysaccharide at $240{ }^{\circ} \mathrm{C}$ [20]. Thus, the reactor wall temperature $\left(300-400{ }^{\circ} \mathrm{C}\right)$ where the water-soluble fractions were recovered is enough to make anhydrosugar polymerize into polysaccharides. Therefore, polysaccharide-based substances in the water-soluble fraction are expected to be formed through thermal polymerization of the anhydrosugars after volatilization and subsequent condensation at the reactor wall.

3.4 Pyrolysis behaviors of wood and its constituent polymers

Figure 7 summarizes the pyrolysis behaviors of wood polysaccharides and lignin as indicated from the present results. In wood polysaccharide pyrolysis, anhydrosugars, $\mathrm{C}_{2}-\mathrm{C}_{3}$ carbonyls, carboxylic acids, furans and $\mathrm{C}_{5}-\mathrm{C}_{6}$ carbonyls are volatilized and condensed at the reactor wall with lower temperature than their boiling points. These products are relatively stable and vapor phase carbonization is not important in wood polysaccharide pyrolysis. Anhydrosugars condensed at the reactor wall are subjected to polymerization into polysaccharides, and their secondary pyrolysis 
including carbonization occurs there. Kawamoto et al [21] proposed that polymerization of levoglucosan into polysaccharides is a key reaction for carbonized product formation from levoglucosan. In this secondary pyrolysis, $\mathrm{C}_{2}-\mathrm{C}_{3}$ carbonyls, furans and $\mathrm{C}_{5}-\mathrm{C}_{6}$ carbonyls would be formed since the literature $[19,22,23]$ shows their formation in cellulose pyrolysis at relatively low temperature of less than $350^{\circ} \mathrm{C}$.

On the other hand, volatiles from lignin are comparatively labile and subjected to the vapor phase carbonization to form the secondary char at the bottom to the upper side of the reactor wall continuously. Only very small amounts of the demethylation products such as catecol-types detected in the tar fraction suggest that homolytic cleavage of phenyl methyl ether may be closely related to carbonization including this vapor phase carbonization.

In wood pyrolysis, these characteristic features became ambiguous as indicated by Fig. 2 . For example, secondary char formation from lignin and wood polysaccharides was substantially suppressed in wood pyrolysis. Composition and the yield of tar fractions from wood are also substantially different from those expected from the results of pyrolysis of the individual components and their composition in wood. Wood formed relatively small amount (4.5 wt\%) of the water-soluble tar fraction, compared to the estimated yield (12.0 wt\%) from the composition (cellulose: 48.6, glucomannan: 11.5, xylan: 7.6, lignin: 32.3 wt\%) of the Japanese cedar wood [24] (Table 3). Furthermore, low hydrolysable sugar content (4.1 wt\%) (cf. 20.6-25.8 wt\% for wood 
polysaccharide samples) (Table 6) and the GPC profile in much lower MW region (Fig. 6) of the water-soluble fraction from wood indicate that nature of the water-soluble fraction from wood is also substantially altered from those of wood polysaccharides samples.

As for the products in the $i$-PrOH-soluble fraction, GPC and GC-MS total ion chromatograms from wood are qualitatively sum of the chromatograms of those from cellulose, glucomannan, xylan and MWL. However, quantitatively, yield of some products are substantially different. For example, peaks of levoglucosan (13) and unknown compound $\mathbf{1 5}$ are quite small in wood in GC-MS analysis (Fig. 4). GC-MS chromatographic pattern of wood is quite different from that of MWL (Fig. 4). From the quantitative results in Table 5, wood tends to form more $\mathrm{C}_{2}-\mathrm{C}_{3}$ carbonyls and levomannosan and less levoglucosan and furans than estimated from the composition of Japanese cedar wood.

Many of these differences between wood and its constituent polymers are expected to be due to inorganic substances in wood. Inorganic substances such as potassium salts are known to suppress the formation of levoglucosan [25-27] and enhance the formation of $\mathrm{C}_{2}-\mathrm{C}_{3}$ carbonyls [28] in wood polysaccharide pyrolysis. For lignin, inorganic substances are reported to decrease the yields of some benzene-type aromatic compounds [29-31]. Our following studies [31,32] indicated some interactions between wood constituent polymers as well as the influence of inorganic matter. 


\section{CONCLUSION}

Pyrolysis behavior of wood was clarified focusing on the difference between wood constituent polymers. Pyrolysis behavior is different between wood polysaccharides and lignin, which includes the tar composition and secondary char formation behavior. It was also indicated that these pyrolysis behaviors are modified in wood pyrolysis. These results will give important information for understanding the overall gasification mechanism on molecular basis.

\section{ACKNOWLEDGEMENT}

This work has been done under the Kyoto University 21 COE program "Establishment of

COE on Sustainable-Energy System” (2002. 4 2007. 3) supported by the Ministry of Education,

Culture, Sports, Science and Technology, Japan. Part of this work is also financially supported by Yamatake Corporation. 


\section{REFERENCES}

[1] T.A. Milne, N. Abatzoglou, R. J. Evance, Biomass Gasifire “Tars”: Their Nature, Formation and Conversion, NREL/TP-570-25357 (1998) p.1-68.

[2] L. Devi, K. J. Ptasinski, F. J. J. G. Janssen, Biomass and Bioenergy, 24 (2003) 125.

[3] D. Sutton, B. Kelleher, J. R. H. Ross, Fuel Processing Technol. 73 (2001) 155.

[4] S. Rapagna, N. Jand, P. U. Foscolo, Intl. J. Hydrogen Energy, 23 (1998) 551.

[5] J. J. M. Órfão, F. J. A. Antunes, J. L. Figueiredo, Fuel 78 (1999) 349.

[6] K. Raveendran. A. Ganesh, K. Khilar, Fuel 75 (1996) 987.

[7] G. Várhegyi, M. J. Antal, Jr., E. Jakab, P. Szabó, J. Anal. Appl. Pyrolysis 42 (1997) 73.

[8] A. D. Pouwels, J. J. Boon, J. Anal. Appl. Pyrolysis 17 (1990) 97.

[9] O. Faix, D. Meier, I. Grobe, J. Anal. Appl. Pyrolysis 11 (1987) 403.

[10] A. D. Pouwels, G. B. Eijkel, J. J. Boon, J. Anal. Appl. Pyrolysis 14 (1989) 237.

[11] R. J. Evans, T. A. Milne, Energy \& Fuels 1 (1987) 123.

[12]T. Koshijima, in T. Haraguchi and N. Moroboshi (Eds.), Mokuzai no Kagaku, Buneido, Tokyo,

5th edn., 1985, Chapter 2, p. 71-72, in Japanese.

[13] A. Bjorkman, Svensk paperstidn 59 (1956) 477.

[14] L. G. Borchardt, C. V. Piper, Tappi 53 (1970) 257.

[15] T. Hosoya, H. Kawamoto, S. Saka, J. Anal. Appl. Pyrolysis, in press. 
[16] K. Miyazaki, Mokuzai Gakkaishi 21 (1975) 120.

[17] D. Gomez-Pardo, J. d’Angelo, Tetrahedron letters 32 (1991) 3067.

[18] E. Heuser, A. Scherer, Brennstoff-Chem. 4 (1923) 97.

[19] F. Shafizadhe, Y. L. Fu, Carbohydr. Res. 29 (1973) 113.

[20] A. Pictet, Helv. Chim. Acta, 1 (1918) 226.

[21] H. Kawamoto, M. Murayama, S. Saka, J. Wood Sci. 49 (2003) 469.

[22] G. N. Richards, J. Anal. Appl. Pyrolysis 10 (1987) 251.

[23] G. N. Richards, F. Shafizadeh and T. T. Stevenson, Carbohydr. Res. 117 (1983) 322.

[24] I. Shimada, K. Shimizu, in M. Masuda, H. Mizumachi, K. Ijima, N. Moroboshi, A. Yamaguchi

(Eds.), Mokuzaikagaku Jikkensho, Tyugaisangyotyosakai, Tokyo, 2nd edn., 1989, Chapter 4, p.146-147, in Japanese.

[25] D. P. C. Fung, Y. Tsuchiya, K. Sumi, Wood Sci. 5 (1972) 38.

[26] Y. Halpern, S. Patai, Isr. J. Chem. 7 (1969) 685.

[27] F. Shafizadeh, R. H. Furneaux, T. G. Cochran, J. P. Scholl, Y. Sakai, J. Appl. Polymer. Sci. 23 (1979) 3525.

[28] J. Piskorz, D. St. A. G. Radlein, D. S. Scott, J. Anal. Appl. Pyrolysis 16 (1989) 127.

[29] R. A. Ripley, D. P. C. Fung, Wood Sci. 4 (1971) 25.

[30] M. Kleen, G. Gellerstedt, J. Anal. Appl. Pyrolysis 35 (1995) 15. 
[31] T. Hosoya, H. Kawamoto, S. Saka, J. Wood. Sci., submitted.

[32] T. Hosoya, H. Kawamoto, S. Saka, J. Anal. Appl. Pyrolysis, submitted. 


\section{Legend of tables and figures}

Table 1 Moisture, ash and hydrolysable sugar contents (wt\%) of the samples.

Table 2 Methods for characterization of pyrolysis products.

Table 3 Fractional compositions after pyrolysis of wood and its constituent polymers (wt\%, oven dry basis).

Table 4 Identification of the products in $i-\mathrm{PrOH}$-soluble fractions by their mass fragments.

Table 5 Yields of some major products from wood and its constituent polymers by oxime-TMS or

CE analysis (yields: wt\%, oven dry basis).

Table 6 Hydrolysable sugar contents of the water-soluble fractions obtained from wood and wood

polysaccharide samples.

Fig. 1. Experimental set-up. 
Fig. 2. Pyrolysis reactors after pyrolysis of wood and its constituent polymers in $\mathrm{N}_{2}$ at $800{ }^{\circ} \mathrm{C}$ for 30 $\mathrm{s}$ with the temperature profile of the furnace.

Fig. 3. GPC chromatograms of $i$-PrOH-soluble fractions obtained from wood and its constituent polymers.

a-d: retention times of 4,4'-dihydroxy-3,3'-dimethoxy-stilbene (a), coniferylaldehyde (b), vanillin and 5-hydroxymethylfurfural (c) and furfural (d), detector: $\mathrm{UV}_{220 \mathrm{~nm}}$.

Fig. 4. Total-ion chromatograms of $i$-PrOH-soluble tar fractions obtained from wood and its constituent polymers in GC-MS analysis.

Fig. 5. ${ }^{1} \mathrm{H}$ NMR spectra of $i-\mathrm{PrOH}$-soluble tar fractions obtained from wood and its constituent polymers after evaporation.

${ }^{* 1}$ water, ${ }^{* 2}$ solvent (acetone), $\bullet$ : levoglucosan, $\mathbf{m}: 5$-HMF, ○: levomannosan.

Fig. 6. GPC chromatograms of water-soluble tar fractions obtained from wood and wood polysaccharide samples. 
a, b: retention times of glucose pentaacetate (a) and levoglucosan triacetate (b), detector: $\mathrm{UV}_{220 \mathrm{~nm}}$.

Fig. 7. Primary pyrolysis behaviors of wood polysaccharides and MWL at gasification temperature. 
Table 1

Moisture, ash and hydrolysable sugar contents (wt\%) of samples.

\begin{tabular}{|c|c|c|c|c|c|c|c|c|}
\hline & \multirow{2}{*}{$\begin{array}{l}\text { Moisture } \\
\text { (wt\%) }\end{array}$} & \multirow{2}{*}{$\begin{array}{c}\text { Ash } \\
\text { (wt\%) }\end{array}$} & \multicolumn{6}{|c|}{ Hydrolysable sugar (wt\%) } \\
\hline & & & Glc & Man & Gal & Xyl & Ara & Total \\
\hline Wood $^{\text {a }}$ & 7.6 & 0.41 & 48.5 & 10.0 & 1.8 & 6.0 & 1.6 & 67.9 \\
\hline Cellulose ${ }^{\mathrm{b}}$ & 8.3 & $\mathrm{nd}^{\mathrm{c}}$ & - & - & - & - & - & - \\
\hline Glucomannan & 7.7 & nd & 16.5 & 68.1 & 4.7 & 6.4 & 1.9 & 97.6 \\
\hline Xylan & 7.5 & nd & 0.5 & 1.7 & nd & 92.4 & nd & 94.6 \\
\hline MWL & 5.1 & nd & 0.6 & 0.3 & nd & 0.7 & 0.2 & 1.8 \\
\hline
\end{tabular}

a hydrolysable sugar content of wood is the data from reference [24].

b hydrolysable sugar content was not measured.

c not detected. 
Table 2

Methods for characterization of pyrolysis products.

\begin{tabular}{|c|c|c|}
\hline Sample & Method & Information \\
\hline \multirow{3}{*}{$\begin{array}{l}i \text {-PrOH-soluble } \\
\text { fraction }^{\text {a }}\end{array}$} & GPC & MW distribution \\
\hline & GC-MS & Low MW products (Qualitative) \\
\hline & ${ }^{1} \mathrm{H}$ NMR & $\begin{array}{l}\text { Low MW + } \\
\text { high MW products (Qualitative) }\end{array}$ \\
\hline \multirow{2}{*}{$\begin{array}{l}\text { Water-soluble } \\
\text { fraction }^{\text {a }}\end{array}$} & GPC (after acetylation) & MW distribution \\
\hline & Hydrolysable sugar content & Polysaccharide \\
\hline $\begin{array}{l}\text { Aceton- } d_{6} \\
\text { extracts }\end{array}$ & ${ }^{1} \mathrm{H}$ NMR & Water content \\
\hline DMF extracts & $\begin{array}{l}\text { Oxime-trimethylsilylation/ } \\
\text { GC-FID }\end{array}$ & Low MW products (Quantitative) \\
\hline Water extracts & Capillary electrophoresis & Organic acid (Quantitative) \\
\hline
\end{tabular}

${ }^{a}$ successive extraction with $i-\mathrm{PrOH}$ and water. 
Table 3

Fractional compositions after pyrolysis of wood and its cell wall constituents (wt\%, oven dry basis).

\begin{tabular}{lcccccc}
\hline & Gas & \multicolumn{3}{c}{ Tar } & \multirow{2}{*}{$\begin{array}{c}\text { Product } \\
\text { water }\end{array}$} & Char \\
\cline { 3 - 5 } & & Total & i-PrOH-soluble & Water-soluble & & \\
\hline Wood & 11.4 & 41.6 & 37.1 & 4.5 & 9.2 & 37.7 \\
Cellulose & 12.9 & 72.0 & 50.4 & 21.6 & 5.1 & 10.0 \\
Glucomannan & 13.0 & 41.3 & 32.3 & 9.0 & 15.3 & 30.4 \\
Xylan & 14.1 & 54.3 & 49.1 & 5.2 & 11.5 & 20.1 \\
MWL & 12.1 & 38.2 & 37.1 & 1.1 & 9.2 & 40.6 \\
\hline
\end{tabular}


Table 4

Identification of the products in $i$-PrOH-soluble fractions by their mass fragments.

\begin{tabular}{|c|c|c|c|}
\hline Compound & MW & Major EI-fragments & Reference $^{a}$ \\
\hline Glycolaldehyde (1) & 60 & $\mathbf{4 4}, 103,87,71,61,56,46,32$ & $\mathrm{R}$ \\
\hline Acetic acid (2) & 60 & $43,61,60,57$ & $\mathrm{R}$ \\
\hline Hydroxyacetone (3) & 74 & $44,75,58$ & $\mathrm{R}$ \\
\hline Furfural (5) & 96 & $95,97,96,80,67,53,51,39,38,29$ & $\mathrm{R}$ \\
\hline 2,5-Dihydro-5-methylfran-2-one (6) & 98 & $\mathbf{9 8}, 99,70,69,55,43,42,41,39,38,29,27$ & L [10] \\
\hline $\begin{array}{l}\text { 2-Hydroxymethylene- } \\
\text { tetrahydrofuran-3-one (7) }\end{array}$ & 114 & $\mathbf{1 1 4}, 115,85,58,57,55,43,42,39,30,29,27$ & $\mathrm{~L}[16,17]$ \\
\hline $\begin{array}{l}\text { 2-Hydroxy-3-methyl-2-cyclopenten- } \\
\text { 1-one (8) }\end{array}$ & 112 & $\mathbf{1 1 2}, 113,84,83,69,56,55,53,43,42,41,39,29,27$ & $\mathrm{R}$ \\
\hline Levoglucosenone (10) & 126 & $\mathbf{6 8}, 98,97,96,81,69,53,52,43,42,39,29$ & $\mathrm{R}$ \\
\hline $\begin{array}{l}\text { 5-Hydroxymethyl-2-tetrahydro- } \\
\text { furaldehyde-3-one (11) }\end{array}$ & 144 & $145,99,85,83,82,70,69,58,57,55,44,43,42,41,40,31,29,27$ & L [10] \\
\hline 5-Hydroxymethylfurfural (12) & 126 & $97,127,126,109,81,69,53,51,41,39,29$ & $\mathrm{R}$ \\
\hline Levoglucosan (13) & 162 & $\mathbf{6 0}, 145,127,97,85,73,69,58,56,44,43,31,29$ & $\mathrm{R}$ \\
\hline Levomannosan (14) & 162 & $\mathbf{6 0}, 73,57,55,45,43,42,31,29$ & $\mathrm{R}$ \\
\hline Guaiacol (16) & 124 & $\mathbf{1 2 4}, 125,109,82,54,53,51,39$ & $\mathrm{R}$ \\
\hline 4-Methylguaiacol (17) & 138 & 138, $139,124,96,68$ & $\mathrm{R}$ \\
\hline 4-Ethylguaiacol (18) & 152 & $\mathbf{1 3 8}, 153,152,139,123,110,95,92,82,80,78,66,54,52,39$ & $\mathrm{R}$ \\
\hline 4-Vinylguaiacol (19) & 150 & $151,136,108,80,78,64,54,52$ & $\mathrm{R}$ \\
\hline Eugenol (20) & 164 & $\mathbf{1 6 4}, 165,150,132,122,104,92,78,56$ & $\mathrm{R}$ \\
\hline Vanillin (21) & 152 & $153,152,124,110,82,66,64,54,53,52,51$ & $\mathrm{R}$ \\
\hline cis-Isoeugenol (22) & 164 & $\mathbf{1 6 4}, 165,150,134,132,122,104,92,78,55$ & $\mathrm{R}$ \\
\hline trans-Isoeugenol (23) & 164 & $\mathbf{1 6 5}, 150,134,132,122,104,92,78,55$ & $\mathrm{R}$ \\
\hline Homovanillin (24) & 166 & $\mathbf{1 3 8}, 167,166,123,95,80,78,67,52,39,29$ & L [9] \\
\hline Acetovanillone (25) & 166 & $167,153,152,124,78,68,66,64,53,44$ & $\mathrm{R}$ \\
\hline Coniferylaldehyde (26) & 178 & $179,181,163,147,135,108,78,53$ & $\mathrm{R}$ \\
\hline Compound 4 & - & $\mathbf{4 3}, 75,42,31,29$ & - \\
\hline Compound 9 & - & $43,128,129,95,72,57,44,29$ & - \\
\hline Compound 15 & - & $55,115,97,86,71,56,44,43,42,29,27$ & - \\
\hline
\end{tabular}

a identified with the authentic compound $(\mathrm{R})$ and the mass fragmentation pattern reported in the literature (L). Bold figure shows base-ion peak. 
Table 5

Yields of some major products from wood and its cell wall constituents determined by oxime-TMS or CE analysis (wt\%, oven dry basis).

\begin{tabular}{|c|c|c|c|c|c|c|c|c|c|c|c|c|c|c|c|c|}
\hline & \multicolumn{3}{|c|}{$\mathrm{C}_{2}-\mathrm{C}_{3}$ Carbonyls } & \multicolumn{4}{|c|}{ Carboxylic acids } & \multicolumn{4}{|c|}{ Anhydrosugars } & \multicolumn{4}{|c|}{ Furans } & \multirow[b]{2}{*}{ Total } \\
\hline & GA & HA & Total & $\begin{array}{c}\text { Formic } \\
\text { acid }\end{array}$ & $\begin{array}{l}\text { Acetic } \\
\text { acid }\end{array}$ & $\begin{array}{l}\text { Glycolic } \\
\text { acid }\end{array}$ & Total & LG & $\mathrm{AF}$ & LM & Total & Fur & 5-HMF & HMTF & Total & \\
\hline Wood & $\begin{array}{c}7.7 \\
{[1.7]^{\mathrm{b}}}\end{array}$ & $\begin{array}{c}1.3 \\
{[2.1]}\end{array}$ & $\begin{array}{c}9.0 \\
{[3.8]}\end{array}$ & 1.8 & 0.74 & 0.39 & 2.9 & $\begin{array}{c}1.2 \\
{[0.32]}\end{array}$ & $\begin{array}{l}\text { trace } \\
{[0.23]}\end{array}$ & $\begin{array}{r}0.61 \\
{[2.7]}\end{array}$ & $\begin{array}{c}1.8 \\
{[3.3]}\end{array}$ & $\begin{array}{c}0.18 \\
{[0.40]}\end{array}$ & $\begin{array}{c}0.28 \\
{[0.55]}\end{array}$ & $\begin{array}{c}\text { trace } \\
{[0.17]}\end{array}$ & $\begin{array}{r}0.46 \\
{[1.1]}\end{array}$ & $14.2\left(38.3^{\mathrm{a}}\right)$ \\
\hline Cellulose & 8.7 & 1.1 & 9.8 & 2.1 & 0.29 & 0.34 & 2.7 & 7.6 & 0.47 & nd & 8.1 & 0.48 & 0.92 & trace & 1.4 & $22.0(43.7)$ \\
\hline Glucomannan & 2.3 & 0.61 & 2.9 & 0.76 & 0.29 & 0.21 & 1.3 & 0.43 & 0.03 & 1.9 & 2.4 & 0.63 & 0.49 & trace & 1.1 & 7.7 (23.9) \\
\hline Xylan & 2.6 & 0.15 & 2.8 & 1.4 & 0.17 & 0.24 & 1.8 & nd $^{c}$ & nd & nd & - & 2.3 & nd & 2.3 & 4.6 & $9.2(18.7)$ \\
\hline
\end{tabular}

GA: glycolaldehyde, HA: hydroxyacetone, LG: levoglucosan, AF: 1,6-anhydro- $\beta$-D-glucofuranose, LM: levomannosan, Fur: furfural, 5-HMF: 5-hydroxymethylfurfural, HMTF: 2-hydroxymethylene-tetrahydrofuran-3-one.

a yield based on the $i$-PrOH-soluble tar fraction.

b (experimental yield from wood pyrolysis) / (estimated yield based on the composition of Japanese cedar wood).

${ }^{\mathrm{c}}$ not detected. 
Table 6

Hydrolysable sugar contents of the water-soluble fractions obtained from wood and wood polysaccharide samples.

\begin{tabular}{lcccc}
\hline & \multicolumn{4}{c}{ Hydrolysable sugar content ${ }^{\mathrm{a}}(\mathrm{wt} \% \mathrm{~b})$} \\
\cline { 2 - 5 } & Glucose & Mannose & Xylose & Total \\
\hline Wood & 2.3 & 0.97 & 0.86 & 4.1 \\
Cellulose & 25.8 & - & - & 25.8 \\
Glucomannan & 4.6 & 19.7 & 0.73 & 25.0 \\
Xylan & - & - & 20.6 & 20.6 \\
\hline
\end{tabular}

a excludes the yield from the monosaccharide including anhydrosugars.

$\mathrm{b}$ based on the water-soluble tar fraction. 


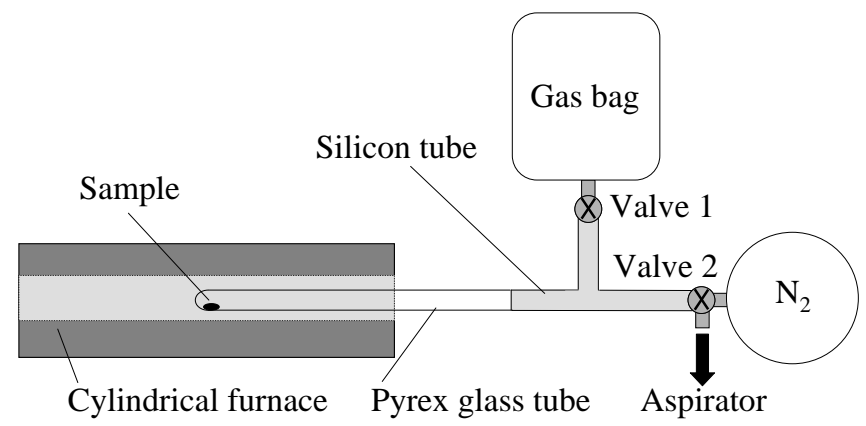

Fig.1 Experimental se-up. 

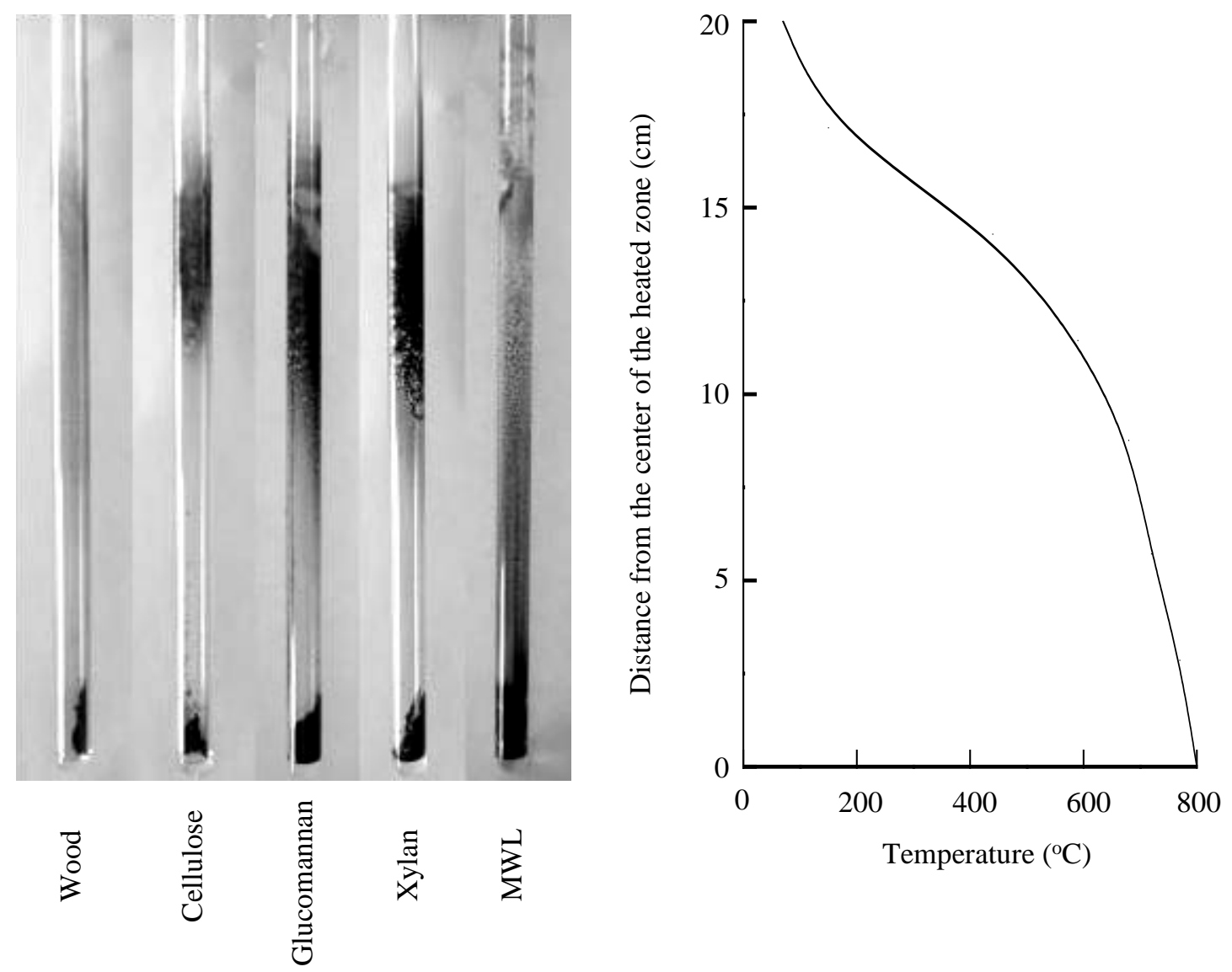

Fig. 2. Pyrolysis reactors after pyrolysis of wood and its constituent polymers in $\mathrm{N}_{2}$ at $800^{\circ} \mathrm{C}$ for 30 $\mathrm{s}$ with the temperature profile of the furnace. 


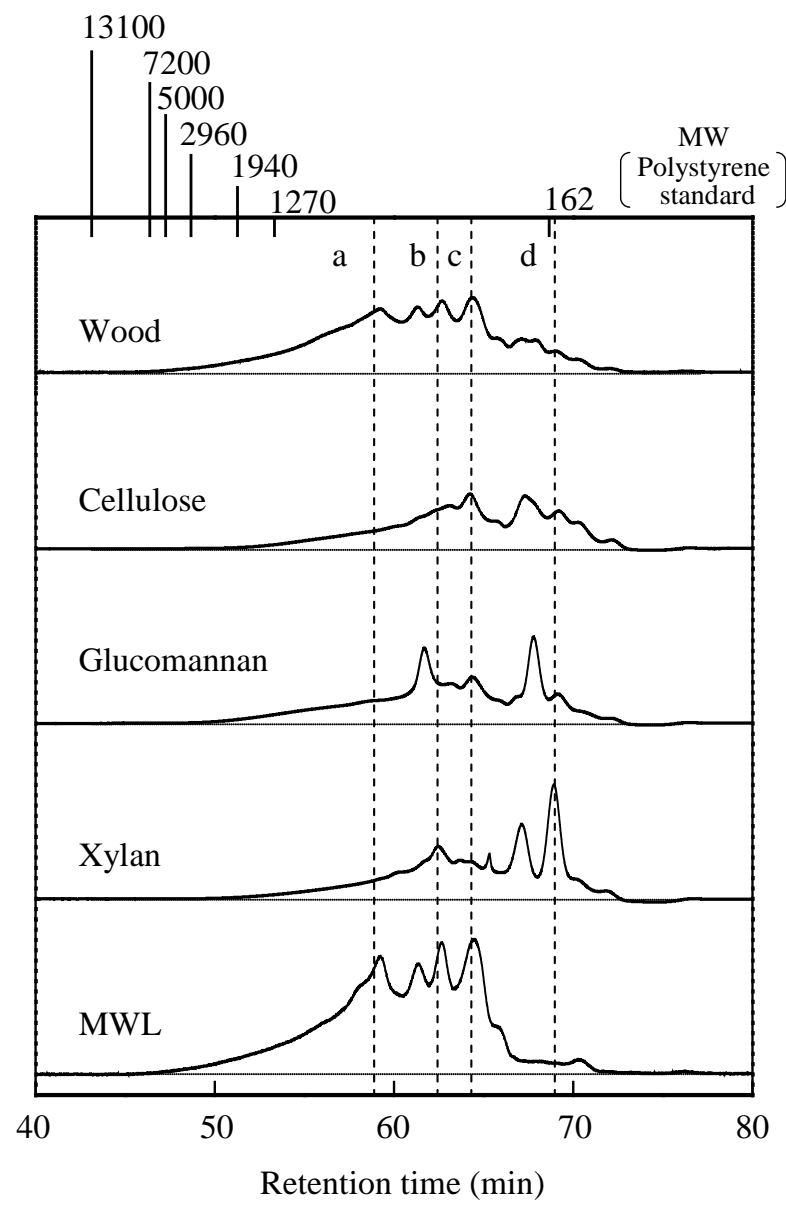

Fig. 3. GPC chromatograms of $i-\mathrm{PrOH}$-soluble fractions obtained from wood and its constituent polymers.

a-d: retention times of 4,4'-dihydroxy-3,3'-dimethoxy-stilbene (a), coniferylaldehyde (b), vanillin and 5-hydroxymethylfurfural (c) and furfural (d), detector: $\mathrm{UV}_{220 \mathrm{~nm}}$. 


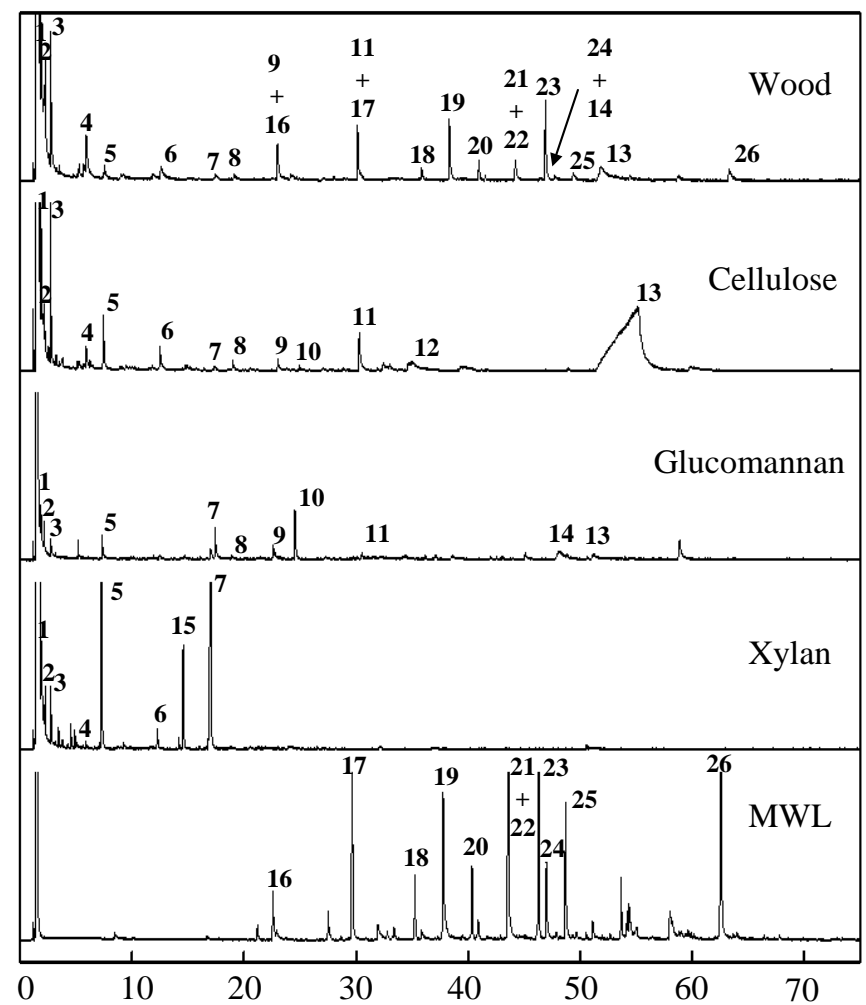

\section{$\mathrm{C}_{2}-\mathrm{C}_{3}$ Carbonyls and} carboxylic acids
1 : Glycolaldehyde
2 : Acetic acid
3 : Hydroxyacetone

\section{Furans and}

$\mathrm{C}_{5}-\mathrm{C}_{6}$ carbonyls

5 : Furfural

6 : 2,5-Dihydro-5-methylfuran2-one

7 : 2-Hydroxymethylenetetrahydrofuran-3-one

8 : 2-Hydroxy-3-methyl-2cyclopenten-1-one]

11: 5-Hydroxymethyl2-tetrahydrofuraldehyde-3-one

12: 5-Hydroxymethylfurfural
Aromatics

16: Guaiacol

17: 4-Methylguaiacol

18: 4-Ethyguaiacol

19: 4-Vinylguaiacol

20: Eugenol

21: Vanillin

22: cis-Isoeugenol

23: trans-Isoeugenol

24: Homovanillin

25: Acetovanillone

26: Coniferylaldehyde

$4,9,15$ : unknown

\section{Anhydrosugars}

10: Levoglucosenone

13: Levoglucosan

14: Levomannosan

Fig. 4. Total-ion chromatograms of $i-\mathrm{PrOH}-$ soluble fractions obtained from wood and its constituent polymers in GC-MS analysis. 


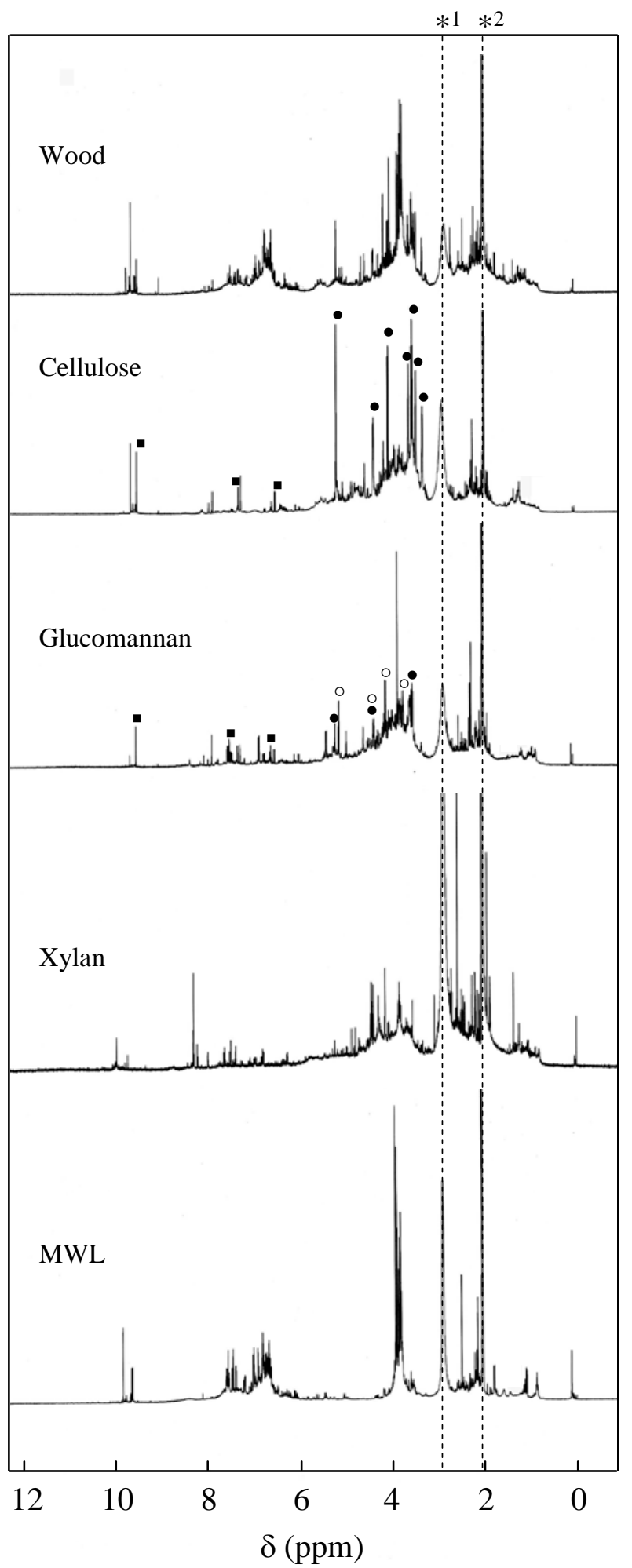

Fig.5. ${ }^{1} \mathrm{H}$ NMR spectra of $i$-PrOH-soluble fractions obtained from wood and its constituent polymers after evaporation.

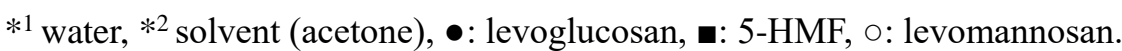




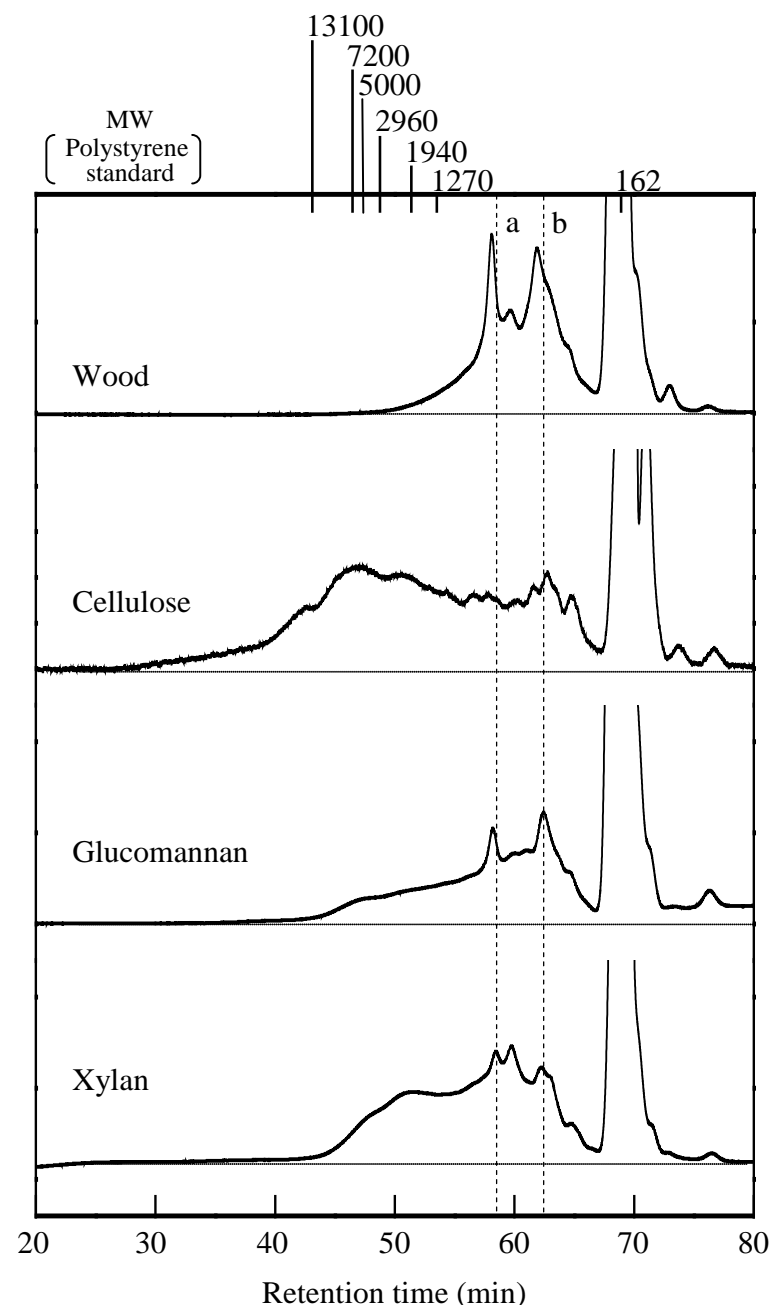

Fig. 6. GPC chromatograms of water-soluble fractions obtained from wood and wood polysaccharide samples.

a, b: retention times of glucose pentaacetate (a) and levoglucosan triacetate (b), detector: $\mathrm{UV}_{220 \mathrm{~nm}}$. 
$\underline{\text { Wood polysaccharides }}$

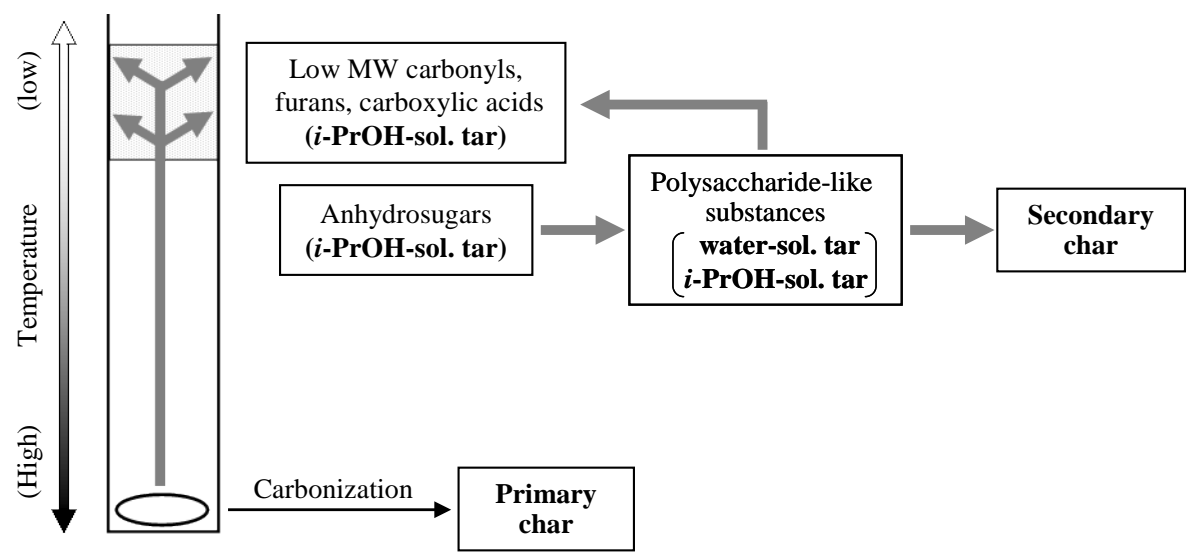

MWL

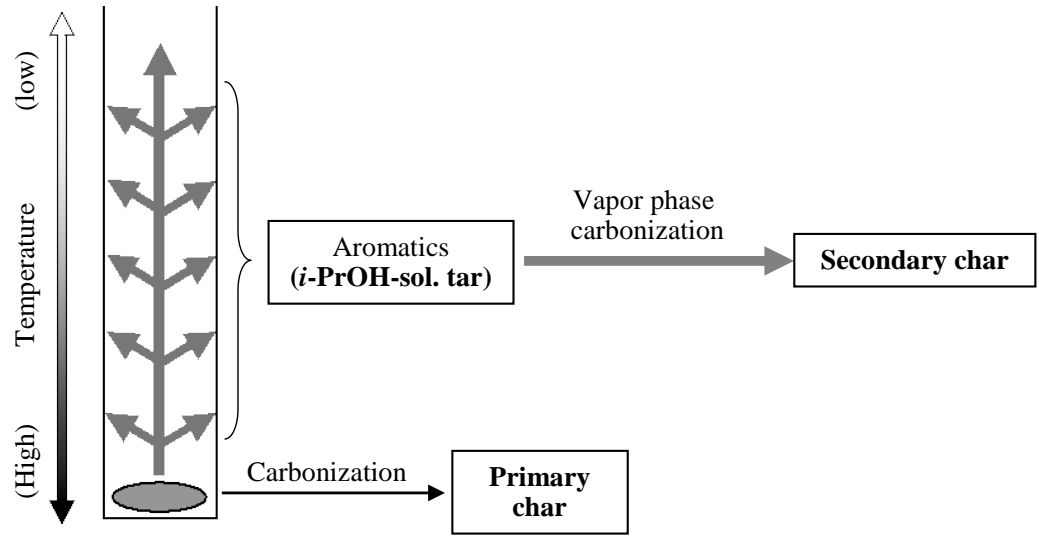

Fig. 7. Primary pyrolysis behaviors of wood polysaccharides and MWL at gasification temperature. 